\title{
Participation of phosphatidyl inositol 3-kinase/protein kinase B and ERK1/2 pathways in interleukin-1 $\beta$ stimulation of lactate production in Sertoli cells
}

\author{
María Fernanda Riera, María Noel Galardo, Eliana Herminia Pellizzari, Silvina Beatriz Meroni \\ and Selva Beatriz Cigorraga
}

Centro de Investigaciones Endocrinológicas (CEDIE), Hospital de Niños 'Ricardo Gutiérrez', Gallo 1330, C1425EFD Buenos Aires, Argentina

Correspondence should be addressed to S B Cigorraga; Email: scigorraga@cedie.org.ar

\begin{abstract}
Interleukin-1 $\beta$ (IL1 $\beta$ ) belongs to a set of intratesticular regulators that provide the fine-tuning of cellular processes implicated in the maintenance of spermatogenesis. The aim of the present study was to analyze the signaling pathways that may participate in IL1 $\beta$ regulation of Sertoli cell function. Sertoli cell cultures from 20-day-old rat were used. Stimulation of the cultures with IL1 $\beta$ showed increments in phosphorylated protein kinase B (PKB), P70S6K, and ERK1/2 levels. A phosphatidyl inositol 3-kinase (PI3K) inhibitor (wortmannin (W)), a mammalian target of rapamycin inhibitor (rapamycin (R)), and a MEK inhibitor (PD98059 (PD)) were utilized to evaluate the participation of PI3K/PKB, P70S6K, and ERK1/2 pathways in the regulation of lactate production by IL1 $\beta$. PD and W, but not R, decreased IL1 $\beta$-stimulated lactate production. The participation of these pathways in the regulation of glucose uptake and lactate dehydrogenase (LDH) A mRNA levels by IL1 $\beta$ was also analyzed. It was observed that $\mathrm{W}$ decreased IL1 $\beta$-stimulated glucose uptake, whereas PD and R did not modify it. On the other hand, PD decreased the stimulation of LDH A mRNA levels by IL1 $\beta$, whereas $W$ and $R$ did not modify it. In summary, results presented herein demonstrate that IL1 $\beta$ stimulates PI3K/PKB-, P70S6K-, and ERK1/2-dependent pathways in rat Sertoli cells. Moreover, these results show that while IL1 $\beta$ utilizes the PI3K/PKB pathway to regulate glucose transport, it utilizes the ERK1/2 pathway to regulate LDH A mRNA levels. This study reveals that IL1 $\beta$ utilizes different signal transduction pathways to modify the biochemical steps that are important to regulate lactate production in rat Sertoli cells.
\end{abstract}

Reproduction (2007) 133 763-773

\section{Introduction}

An adequate Sertoli cell function is essential for the normal development of spermatogenesis. These testicular cells are under the control of follicle-stimulating hormone $(\mathrm{FSH})$ and a plethora of locally produced factors that contribute to the normal functioning of the testis (Gnessi et al. 1997). The above-mentioned factors bind to specific receptors and activate different signaling pathways. As a result of this complex network of signaling molecules, poorly analyzed in Sertoli cells so far, a biological response occurs.

Interleukin-1 $\beta$ (IL1 $\beta$ ) belongs to a set of local testicular regulators and is produced by interstitial macrophages and Leydig cells (Lin et al. 1993, Hayes et al. 1996). In addition, it has been shown that IL1 receptor type I and II mRNAs are constitutively expressed in Sertoli cell cultures (Gomez et al. 1997). Several roles of IL1 $\beta$ in the regulation of Sertoli cell function have been previously studied (Khan \& Nieschlag 1991, Okuda et al. 1995, Hoeben et al. 1996a, 1996b, Nehar et al. 1998, Meroni et al. 2000, Riera et al. 2001, Petersen et al. 2002). However, with few exceptions, these reports have not investigated the signal transduction pathways utilized by this cytokine to regulate Sertoli cell function. It is known that IL1 $\beta$ activates a large number of signal transduction pathways in different cell types. One of the signals usually elicited by IL1 $\beta$, which is intimately associated to the inflammatory response, is the one that results in the translocation of the transcription factor $\mathrm{NF \kappa B}$ to the nucleus (Sizemore et al. 1999). In this regard, we have previously shown that IL $1 \beta$ promotes $\mathrm{NF} \kappa \mathrm{B}$ activation and its nuclear translocation, as well as the expression of iNOS protein and subsequent $\mathrm{NO}$ production in the Sertoli cells (Meroni et al. 2000). In the latter report, we have also shown that this signal transduction pathway is partly responsible for the 
IL1 $\beta$-stimulated $\gamma$ GTP activity observed in Sertoli cell cultures. Recently, a report appeared showing that in Sertoli cells, the expression of STAR-related (START) domain-containing proteins is regulated by IL1 $\beta$ using mechanisms that involve the activation of c-Jun $\mathrm{N}$-terminal kinase (JNK) and inducible COX-2 pathways (Ishikawa et al. 2005). So far, neither the participation of the above-mentioned nor of other signaling pathways in the regulation of additional Sertoli cell biological responses by IL1 $\beta$ has been analyzed.

A few years ago, a link between IL1 $\beta$ binding to its receptor and phosphatidyl inositol 3-kinase (PI3K) activation in several cell lines was observed (Reddy et al. 1997). PI3K is a key enzyme implicated in the regulation of a broad array of biological responses, including receptor-stimulated mitogenesis, oxidative burst, membrane ruffling, and glucose uptake (Rameh \& Cantley 1999). Agonist-stimulated PI3K phosphorylates the D-3 position of the inositol ring of phospholipids, generating potential second messengers that participate in the activation of protein kinases such as protein kinase B (PKB; Vanhaesebroeck \& Alessi 2000) and p70 S6 kinase (P70S6K; Proud 1996). PKB is activated by phospholipid binding and phosphorylation at Thr308 and Ser473 by specific kinases such as PDK1, a downstream effector of PI3K (Alessi et al. 1996). On the other hand, P70S6K, which was originally recognized as the kinase that regulates the multiple phosphorylation of the $40 \mathrm{~S}$ ribosomal protein S6 in vivo, leads to up-regulation of ribosome biosynthesis and increases the translational capacity of the cell. Activation of P70S6K also involves the phosphorylation at multiple serine/threonine residues (Pullen \& Thomas 1997). Recent studies have shown that at least two signaling pathways influence P70S6K activity. One of these pathways involves PI3K, PDK1, and perhaps also PKB (Martin et al. 2001). The other pathway that is essential for P70S6K activation involves the mammalian target of rapamycin (mTOR).

Another signaling pathway through which IL1 $\beta$ apparently mediates its regulatory response in several cell types involves the ubiquitous MAPK pathway (Gould et al. 1995, Finch et al. 2001). MAPK cascades are typically organized in three-kinase architecture consisting of a MAPK, a MAPK activator (MEK, MKK, or MAPKK), and a MEK activator (MEK or MAPKK). Transmission of signals is achieved by sequential phosphorylation and activation of the components specific to a respective cascade. In mammalian systems, three principal MAPK modules have been identified. These include the ERK $1 / 2$ cascade, the JNK cascade, and the p38 MAPK cascade. The ERK1/2 cascade was first implicated in the regulation of cell growth and proliferation. However, it is presently known that this kinase also participates in the control of cellular metabolism and morphology, apoptosis, and carcinogenesis (Pearson et al. 2001).
We have previously shown that IL1 $\beta$ stimulates lactate production, glucose uptake, and lactate dehydrogenase (LDH) activity (Riera et al. 2001). However, the precise molecular and biochemical mechanisms involved in IL1 $\beta$ regulation of the above-mentioned Sertoli cell functions remain largely unknown. Therefore, the aim of the present study was to determine: a) whether IL $1 \beta$ is able to stimulate PKB-, P70S6K-, and ERK1/2-signaling pathways in Sertoli cells and b) to what extent these signaling pathways participate in the IL $1 \beta$ regulation of lactate production in Sertoli cell.

\section{Materials and Methods}

\section{Materials}

Rat recombinant IL1 $\beta$ was purchased from SigmaAldrich.

Wortmannin, LY294002, U0126, and PD98059 were purchased from Biomol (Plymouth Meeting, PA, USA) and rapamycin was purchased from New England Biolabs Inc. (Beverley, MA, USA). $\left[2,6-{ }^{3} \mathrm{H}\right] 2$-deoxy-Dglucose $\left(\left[2,6^{3} \mathrm{H}\right] 2-\mathrm{DOG}\right)$ was purchased from NEN (Boston, MA, USA). Kodak X-Omat $S$ films were purchased from Eastman Kodak. All other drugs and reagents were obtained from Sigma-Aldrich.

\section{Sertoli cell isolation and culture}

Sertoli cells from 20-day-old Sprague-Dawley rats were isolated as previously described (Meroni et al. 1999). Briefly, decapsulated testes were digested with $0.1 \%$ collagenase and $0.006 \%$ soybean trypsin inhibitor in Hanks' balanced salt solution for $5 \mathrm{~min}$ at room temperature. Seminiferous tubules were preserved, cut, and subjected to $1 \mathrm{M}$ glycine-2 mM EDTA $(\mathrm{pH} 7.4)$ treatment to remove peritubular cells. The washed tubular pellet was then digested again with collagenase for $10 \mathrm{~min}$ at room temperature to remove germinal cells. The Sertoli cell suspension, collected by sedimentation, was resuspended in a culture medium consisting of a 1:1 mixture of Ham's F12 and Dulbecco's modified Eagle medium, supplemented with $20 \mathrm{mM}$ HEPES, $100 \mathrm{IU} / \mathrm{ml}$ penicillin, $2.5 \mu \mathrm{g} / \mathrm{ml}$ amphotericin $\mathrm{B}$, $1.2 \mathrm{mg} / \mathrm{ml}$ sodium bicarbonate, $10 \mu \mathrm{g} / \mathrm{ml}$ transferrin, $5 \mu \mathrm{g} / \mathrm{ml}$ insulin, $5 \mu \mathrm{g} / \mathrm{ml}$ vitamin $\mathrm{E}$, and $4 \mathrm{ng} / \mathrm{ml}$ hydrocortisone. An adequate aliquot of this cell suspension was preserved and DNA content was determined immediately. DNA levels were used to standardize the cell density in the cultures (Schteingart et al. 1995). Sertoli cells were cultured in 6-, 24-, or 96-multiwell plates or in $25 \mathrm{~cm}^{2}$ tissue culture flasks at a constant density of $5 \mu \mathrm{g} \mathrm{DNA} / \mathrm{cm}^{2}$, at $34{ }^{\circ} \mathrm{C}$ in a mixture of $5 \%$ $\mathrm{CO}_{2}-95 \%$ air.

No myoid cell contamination was revealed in the cultures when an immunoperoxidase technique was applied to Sertoli cell cultures using a specific antiserum 
to $\alpha$-smooth muscle actin. Remaining cell contaminants were of germ cell origin and this contamination was below $5 \%$ after $48 \mathrm{~h}$ in culture, as examined by phase contrast microscopy.

\section{Culture conditions}

Sertoli cells were allowed to attach for $48 \mathrm{~h}$ in the presence of insulin, and the medium was replaced at this time with fresh medium without insulin.

Stimulation with IL $1 \beta$ was performed on day 3 in the absence or presence of PI3K, mTOR, and MEK inhibitors (wortmannin, rapamycin, and PD98059) as indicated in figure legends. In all cases, the inhibitors were added 15 min prior to the addition of IL1 $\beta$. The 72-h conditioned media obtained on day 6 was used to evaluate the lactate and transferrin levels. Cells harvested on day 6 were used to determine LDH and $\gamma$ GTP activities. To determine mRNA levels for LDH A, cells stimulated for $48 \mathrm{~h}$ and collected on day 5 were utilized.

For 2-deoxyglucose uptake studies, cells harvested on day 5 and pretreated for $1 \mathrm{~h}$ with IL1 $\beta$ in the absence or presence of the above-mentioned inhibitors were used.

Cells harvested on day 6 and cultured on six-well plates, pretreated as indicated in the figure legends, were used for western blot analysis of phosphorylated PKB, P70S6K, and ERK1/2 (P-PKB, P-P70S6K, and P-ERK1/2) levels.

\section{Cell extracts and western blot analysis}

Cells were washed once with PBS at room temperature. Then, $200 \mu \mathrm{l}$ PBS containing $20 \mu \mathrm{l}$ protease inhibitor cocktail from Sigma-Aldrich (P-8340) and $2 \mathrm{mM}$ phenylmethylsulfonylfluoride were added to the cells. Cells were then placed on ice and disrupted by ultrasonic irradiation. Protein content in the samples was determined by Lowry's assay (Lowry et al. 1951). Two hundred microliters of $2 \times$ Laemmli buffer ( $4 \% \mathrm{w} / \mathrm{v}$ SDS, $20 \% \mathrm{v} / \mathrm{v}$ glycerol, $10 \% \mathrm{v} / \mathrm{v} 2$-mercaptoethanol, $0.004 \%$ $\mathrm{w} / \mathrm{v}$ bromophenol blue, and $0.125 \mathrm{M}$ Tris- $\mathrm{HCl}, \mathrm{pH} 6.8$ ) were added and thoroughly mixed (Laemmli 1970). Samples were immersed in a boiling water bath for $5 \mathrm{~min}$ and then immediately settled on ice. Forty micrograms of protein aliquots were seeded in each lane. Proteins were resolved in 10\% SDS-PAGE (10\% acrylamide/bisacrylamide for the resolving gel and $4.3 \%$ acrylamide/ bisacrylamide for the stacking gel) in a mini protean 3 cell (Bio-Rad). After SDS-PAGE, gels were equilibrated in transfer buffer for $10 \mathrm{~min}$ and electrotransferred at $100 \mathrm{~V}$ for $60 \mathrm{~min}$ onto PVDF membranes (Hybond-P, Amersham Pharmacia Biotech) using a mini trans-blot cell (Bio-Rad). Membranes were probed with commercial kits (phosphoplus Akt (Ser473) antibody kit, phosphoplus P70 S6 kinase (Thr421/Ser424) antibody kit, and phosphoplus p44/42 MAPK (Thr202/Tyr204) antibody kit; New England Biolabs Inc.) that allow specific recognition of both total (T-PKB, T-P70S6K, and T-ERK1/2) and phosphorylated (P-PKB, P-P70S6K, and P-ERK1/2) PKB, P70S6K, and ERK1/2. A 1:1000 dilution of primary antibodies, as indicated by the kit manufacturer, was used. The intensities of the autoradiographic bands were estimated by densitometric scanning using $\mathrm{NIH}$ Image software (Scion Corporation, Frederick, MD, USA). Levels of the corresponding total PKB, P70S6K, and ERK $1 / 2$ served as loading controls.

\section{Measurement of 2-DOG uptake}

Glucose transport was studied using the uptake of the labeled non-metabolizable glucose analog 2-DOG. Cells were washed thrice with glucose-free PBS at room temperature. Then, Sertoli cells were incubated at $34{ }^{\circ} \mathrm{C}$ in $0.5 \mathrm{ml}$ glucose-free PBS containing $\left[2,6-{ }^{3} \mathrm{H}\right] 2-$-DOG $(0.5 \mu \mathrm{Ci} / \mathrm{ml})$ for $30 \mathrm{~min}$. Unspecific uptake was determined in incubations performed in the presence of a 10000 -fold higher concentration of unlabeled 2-DOG. At the end of the incubation period, dishes were placed on ice and extensively washed with ice-cold PBS until no radioactivity was present in the washings. Cells were then dissolved in $0.5 \mathrm{M}$ sodium hydroxide and $0.4 \%$ sodium deoxycholate, and counted in a liquid scintillation spectrophotometer. Parallel cultures receiving identical treatments to those performed before the glucose uptake assay were destined to DNA determinations. 2-DOG incorporation into the cells was normalized, considering the amount of DNA in the cultures.

\section{Lactate determination}

Lactate was measured by a standard method involving conversion of $\mathrm{NAD}^{+}$to $\mathrm{NADH}$, determined as the rate of increase of absorbance at $340 \mathrm{~nm}$. A commercial kit from Sigma-Aldrich was used.

\section{Analysis of LDH A mRNA levels}

Total RNA was isolated from Sertoli cells cultured in $25 \mathrm{~cm}^{2}$ tissue culture flasks with TRI reagent, a monophasic solution of phenol and guanidine isothiocyanate. The amount of RNA was estimated by spectrophotometry at $260 \mathrm{~nm}$. About $20 \mu \mathrm{g}$ total RNA were electrophoresed on a $1 \%$ agarose- $10 \%$ formaldehyde gel. After migration, RNAs were transferred to Hybond-N nylon membrane (Amersham Pharmacia Biotech) by capillary transfer with $20 \times$ SSC $(20 \times$ stock solution: $3 \mathrm{M} \mathrm{NaCl}$ and $0.3 \mathrm{M}$ sodium citrate, $\mathrm{pH} 7.4$ ) and fixed with U.V. Stratalinker (Stratagene Cloning Systems, La Jolla, CA, USA). Complete rat LDH A 3'UTR cDNA cloned into pBluescript (Accession number NM 017025) was gently provided by $R$ Jungmann, 
Northwestern University Medical School, Chicago, IL, USA. The probe obtained by digestion with Pst I-BgI II (bases 1143-1534) was labeled with $\left[\boldsymbol{\alpha}^{32} \mathrm{P}\right]$ deoxy-CTP (Amersham Pharmacia Biotech) using a random-primed labeling kit (Stratagene Cloning Systems). Blots were prehybridized for $5 \mathrm{~h}$ at $42{ }^{\circ} \mathrm{C}$ in $50 \%$ formamide, $\mathrm{NaCl} /$ Pi/EDTA $(0.75 \mathrm{M} \mathrm{NaCl}, 20 \mathrm{mM}$ sodium phosphate $(\mathrm{pH}$ 7.5), and $1 \mathrm{mM}$ EDTA), $5 \times$ Denhardt solution, $10 \%$ dextran sulfate, $0.5 \%$ SDS, and $100 \mu \mathrm{g} / \mathrm{ml}$ herring sperm DNA. Hybridization was then performed overnight at $42{ }^{\circ} \mathrm{C}$ in the same hybridization buffer containing $1-4$ $\times 10^{6}$ c.p.m. $/ \mathrm{ml}{ }^{32}$ P-labeled probe. Membranes were washed twice in $2 \times$ SSC $-0.5 \%$ SDS $(20 \mathrm{~min}$, room temperature) followed by two washes in $1 \times$ SSC $-0.1 \%$ SDS (30 min, $65^{\circ} \mathrm{C}$ ). Membranes were exposed to Kodak $\mathrm{X}$-Omat $\mathrm{S}$ films (Eastman Kodak) for $1-2$ days at $-70{ }^{\circ} \mathrm{C}$. The intensities of the autoradiographic bands were estimated by densitometric scanning using NIH Image software (Scion Corporation). The $18 \mathrm{~S}$ signal was used to standardize LDH A mRNA content.

\section{LDH activity measurement}

Cells were disrupted by ultrasonic irradiation in $0.9 \%$ $\mathrm{NaCl}$ and aliquots were preserved for DNA determinations. The remaining material was centrifuged at $15800 \mathrm{~g}$ for $10 \mathrm{~min}$. The supernatant was used to measure total LDH activity, which was determined by a routinely used spectrophotometric method (Wiener Laboratories, Rosario, Argentina). Results were expressed as mlU per $\mu \mathrm{g}$ DNA.

\section{$\gamma$-Glutamyl transpeptidase assay}

$\gamma$ GTP activity was assayed by the method of Orlowsky \& Meister (1963), using L- $\gamma$-glutamyl- $p$-nitroanilide as substrate and glycylglycine as the acceptor molecule. Sertoli cell monolayers were disrupted by ultrasonic irradiation in $0.5 \mathrm{ml}$ reaction buffer $\left(0.1 \mathrm{M}\right.$ Tris buffer, $0.01 \mathrm{M} \mathrm{MgCl}_{2}$, and $0.02 \mathrm{M}$ glycylglycine, $\mathrm{pH}$ 9). Adequate aliquots for DNA determinations were preserved and $5 \mathrm{mM}$ substrate ( $\mathrm{L}-\gamma$-glutamyl-p-nitroanilide) was added to the remaining material. The reaction was allowed to proceed for 120 min at $34{ }^{\circ} \mathrm{C}$, and the enzymatic reaction was stopped by the addition of acetic acid up to a $1 \mathrm{M}$ concentration. Samples were then centrifuged and absorbances determined in a spectrophotometer at $410 \mathrm{~nm}$. Values were compared against a standard curve with increasing concentrations of $p$-nitroaniline. Results were expressed as pmol $p$-nitroaniline produced per min per $\mu \mathrm{g}$ DNA in the culture.

\section{Cell viability test}

A cell viability test was performed in cells cultured on 96-well plates and treated for 3 or $72 \mathrm{~h}$ with wortmannin
$(0.1 \mu \mathrm{M})$, LY294002 $(25 \mu \mathrm{M})$, rapamycin (1 nM), U0126 $(1 \mu \mathrm{M})$, or PD98059 $(10 \mu \mathrm{M})$. A commercial kit (CellTiter 96 Aqueous Non-Radioactive Cell Proliferation Assay, Promega Corporation) was used.

\section{Transferrin determination}

Rat transferrin (rTF) was measured by RIA as described by Handelsman et al. (1989). A polyclonal antibody raised against rTF in rabbits was used (Cappel Laboratories, Cochranville, PA, USA). The cross-reactivity of human transferrin in this assay is $<0.003 \%$. Unconditioned medium containing $10 \mu \mathrm{g} / \mathrm{ml}$ human TF did not show any cross-reactivity in this assay. This RIA has a sensitivity of $3 \mathrm{ng} /$ tube and intra- and interassay coefficients of variation are 7 and $16 \%$ respectively.

\section{Other assays}

DNA was determined by the method of Labarca \& Paigen (1980).

\section{Statistical analysis}

All experiments were run in triplicates and repeated 3-4 times. One-way ANOVA and post hoc analysis using Tukey-Kramer's multiple comparisons test were performed using GraphPad InStat version 3.00 for Windows 95 (GraphPad Software, San Diego, CA, USA). P values $<0.05$ were considered statistically significant.

\section{Results}

\section{IL1 $\beta$ increases phosphorylated PKB, P70S6K, and ERK1/2 levels in rat Sertoli cells}

Sertoli cell cultures were stimulated for variable periods of time $(5,15$, and $30 \mathrm{~min})$ with $50 \mathrm{ng} / \mathrm{ml} \mathrm{IL} 1 \beta$, a concentration that has been shown to elicit maximal biological responses (Meroni et al. 2000). Stimulation of the cultures with IL1 $\beta$ showed time-dependent increments in P-PKB, P-P70S6K, and P-ERK1/2 levels reaching maximal stimulus in 15-min incubations for P-PKB and P-ERK1/2 levels and in 30-min incubations for P-P70S6K levels (Fig. 1). Pooled data obtained in three independent experiments performed with $50 \mathrm{ng} / \mathrm{ml} \mathrm{IL1} \beta$ revealed $4.4 \pm 0.6-, 3.5 \pm 0.3-$, and $4.1 \pm 0.9$-fold stimulation (mean \pm s.E.M.) in P-PKB, P-P70S6K, and P-ERK1/2 levels respectively.

We next examined whether the $\mathrm{PI} 3 \mathrm{~K}$ inhibitors (wortmannin and LY 294002), the mTOR inhibitor (rapamycin), and the MEK inhibitors (PD98059 and U0126) were able to block the stimulatory effects of IL1 $\beta$ on P-PKB, P-P70S6K, and P-ERK1/2 levels. The cells were preincubated for $15 \mathrm{~min}$ with the inhibitors and then stimulated with IL1 $\beta$. Figure $2 A$ and B shows that wortmannin and LY294002 decreased the ability of 

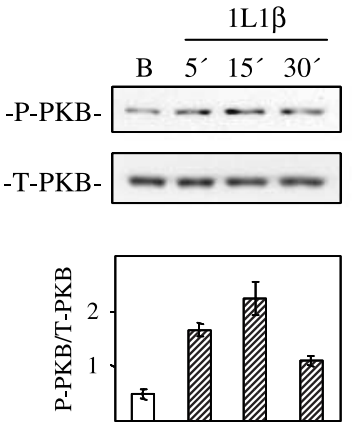
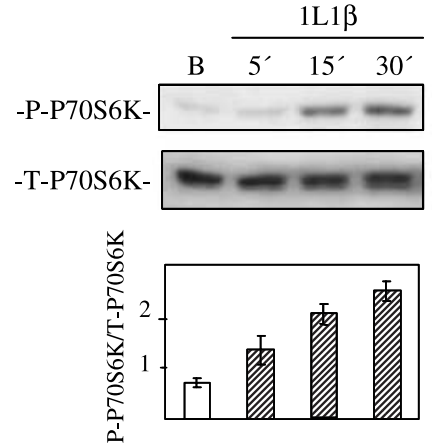
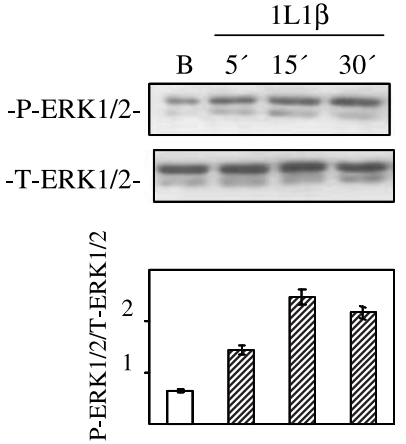

Figure 1 Effect of IL1 $\beta$ on P-PKB, P-P70S6K, and P-ERK1/2 levels in rat Sertoli cells. Sertoli cells were stimulated for variable periods of time (5, 15, or $30 \mathrm{~min}$ ) with $50 \mathrm{ng} / \mathrm{ml} \mathrm{IL1 \beta}$. Cell extracts were prepared at the designated intervals and utilized for western blot analysis using antibodies specific for (A) P-PKB or T-PKB, (B) P-P70S6K or T-P70S6K, and (C) P-ERK1/2 or T-ERK1/2. The upper panels show a representative experiment out of three. The lower panels show pooled data of the three independent experiments performed. Results are expressed as the mean \pm s.E.M. of the ratio between P-PKB and T-PKB, P-P70S6K and T-P70S6K, and P-ERK1/2 and T-ERK1/2 in each sample.

IL1 $\beta$ to increase the levels of P-PKB and that rapamycin and PD98059 (C) did not modify it. Figure 2D shows that wortmannin and LY294002 did not modify basal P-PKB levels. On the other hand, Fig. 3 shows that rapamycin (A) and wortmannin (B) decreased IL1 $\beta$ stimulation of P-P70S6K levels and that PD98059 (C) did not modify it. Figure 3D shows that rapamycin and wortmannin did not modify the low levels of basal P-P70S6K. Finally, Fig. 4 shows that PD98059 and U0126 decreased the ability of IL1 $\beta$ to stimulate P-ERK1/2 levels (A and B), but neither wortmannin nor rapamycin $(C)$ modified it. Figure $4 \mathrm{D}$ shows that PD98059 and U0126 did not modify the low levels of basal ERK1/2.

\section{Distinct signal transduction pathways participate in IL1 $\beta$ regulation of Sertoli cell function}

As mentioned previously in the introduction, the expression of iNOS and NO production are partly responsible for the IL1 $\beta$-stimulated $\gamma$ GTP activity observed in Sertoli cell cultures. The participation of PI3K-, P70S6K-, and ERK1/2-signaling pathways in IL1 $\beta$ regulation of $\gamma$ GTP activity was evaluated in the present study. Table 1 shows that wortmannin, rapamycin, and PD98059 did not modify IL1 $\beta$ stimulation of $\gamma$ GTP activity.

On the other hand, aminoguanidine (AG; $1 \mathrm{mM}$ ), a well-known NOS inhibitor, did not modify IL1 $\beta$ stimulation of lactate production (basal: $7.3 \pm 0.9^{*}$; IL1 $\beta$ : $21.2 \pm 4.8^{+} ;$IL1 $\beta+$ AG: $23.2 \pm 3.8^{+} \mu \mathrm{g} / \mu \mathrm{g}$ DNA, $X \pm$ s.D., ${ }^{*},+$ indicate statistically significant differences, $P<0.05)$. The next set of experiments intended to determine whether IL1 $\beta$-stimulated PI3K/PKB, P70S6K, and ERK $1 / 2$ signaling pathways were relevant to the regulation of lactate production. The inhibitors wortmannin, LY294002, rapamycin, PD98059, and U0126 were added to the cultures $15 \mathrm{~min}$ prior to the initiation of a $72-\mathrm{h}$ incubation period with IL1 $\beta$. A cell viability test
A
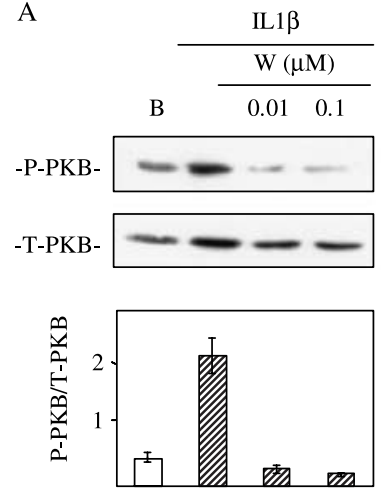

C
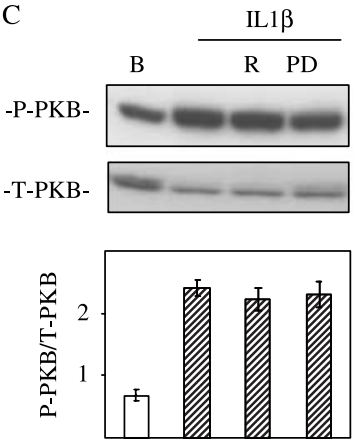

B
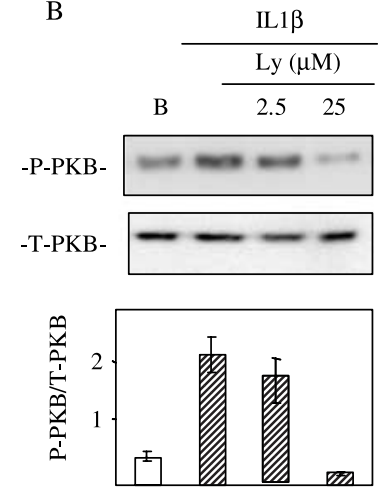

$\mathrm{D}$
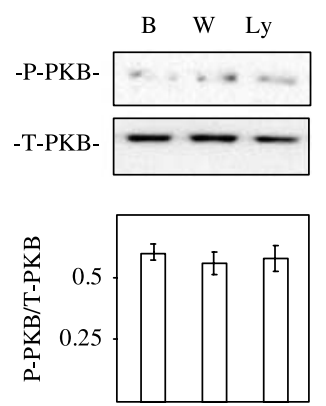

Figure 2 Effect of $W, L y, R$, and PD on IL1 $\beta$-stimulated P-PKB levels in rat Sertoli cells. (A-C) Sertoli cells preincubated or not for $15 \mathrm{~min}$ with wortmannin (W; 0.01 and $0.1 \mu \mathrm{M})$, LY294002 (Ly; 2.5 and $25 \mu \mathrm{M})$, rapamycin ( $\mathrm{R} ; 1 \mathrm{nM})$, or PD98059 (PD; $10 \mu \mathrm{M})$ were stimulated for $15 \mathrm{~min}$ with $50 \mathrm{ng} / \mathrm{ml} \mathrm{IL1} \beta$. (D) Sertoli cells incubated or not for $30 \mathrm{~min}$ with wortmannin (W; $0.1 \mu \mathrm{M})$ or LY294002 (Ly; $25 \mu \mathrm{M})$. Cell extracts were prepared at the designated intervals and utilized for western blot analysis using antibodies specific for P-PKB or T-PKB. The upper panels show a representative experiment out of three. The lower panels show pooled data of the three independent experiments performed. Results are expressed as the mean \pm s.E.M. of the ratio between P-PKB and T-PKB in each sample. 

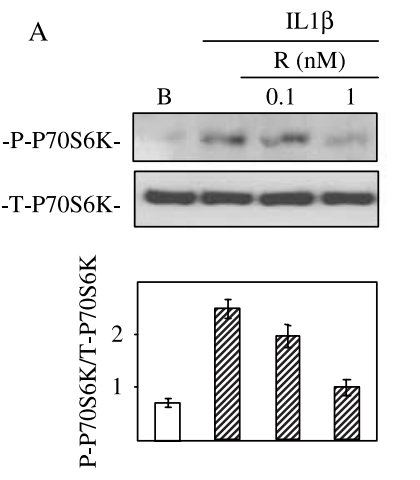

$\mathrm{C}$
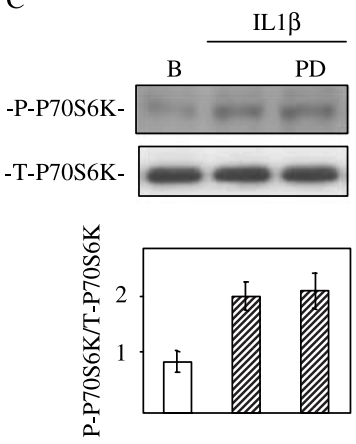
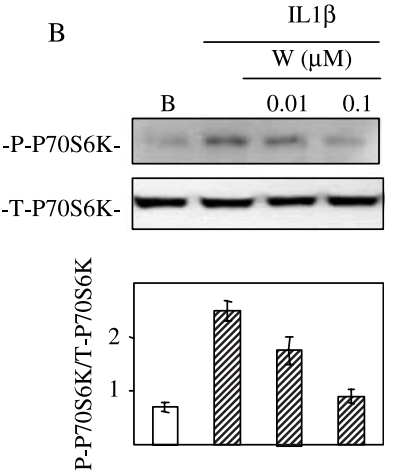

$\mathrm{D}$
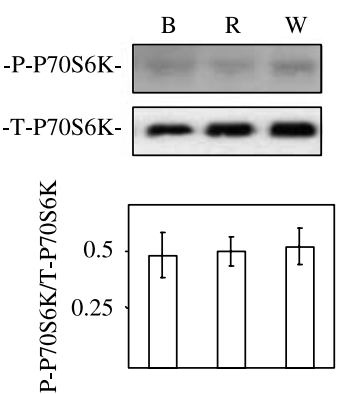

Figure 3 Effect of R, W, and PD on IL1 $\beta$-stimulated P-P70S6K levels in rat Sertoli cells. (A-C) Sertoli cells preincubated or not for $15 \mathrm{~min}$ with rapamycin $(\mathrm{R} ; 0.1$ and $1 \mathrm{nM})$, wortmannin $(\mathrm{W} ; 0.01$ and $0.1 \mu \mathrm{M})$, or PD98059 (PD; $10 \mu \mathrm{M}$ ) were stimulated for $30 \mathrm{~min}$ with $50 \mathrm{ng} / \mathrm{ml}$ IL1 $\beta$. (D) Sertoli cells incubated or not for 45 min with rapamycin ( $R ; 1 \mathrm{nM})$ or wortmannin $(\mathrm{W} ; 0.1 \mu \mathrm{M})$. Cell extracts were prepared at the designated intervals and utilized for western blot analysis using antibodies specific for P-P70S6K or T-P70S6K. The upper panels show a representative experiment out of three. The lower panels show pooled data of the three independent experiments performed. Results are expressed as the mean \pm S.E.M. of the ratio between P-P70S6K and T-P70S6K in each sample.

performed at the end of 3- and 72-h incubation periods showed that, except for LY294002 in 72-h incubations, the inhibitors used had no effect on cell viability (Table 2).

Figure 5 shows that wortmannin and PD98059 decreased IL1 $\beta$-stimulated lactate production, whereas rapamycin did not modify it. In order to rule out that the lack of effect of rapamycin was due to a decrease in the biological activity of the inhibitor caused by incubations during prolonged periods of time, the effect of rapamycin on another Sertoli cell biological response was tested. Table 3 shows that rapamycin inhibited IL1 $\beta$ stimulation of transferrin levels in a $72-h$ incubation period.

Figure 6 shows that wortmannin decreased the ability of IL1 $\beta$ to stimulate glucose uptake, while PD98059 and rapamycin did not modify it. On the other hand, Fig. 7 shows that while wortmannin and rapamycin were not able to modify IL1 $\beta$-stimulated LDH A mRNA levels, PD98059 exerted an inhibitory effect. U0126, another
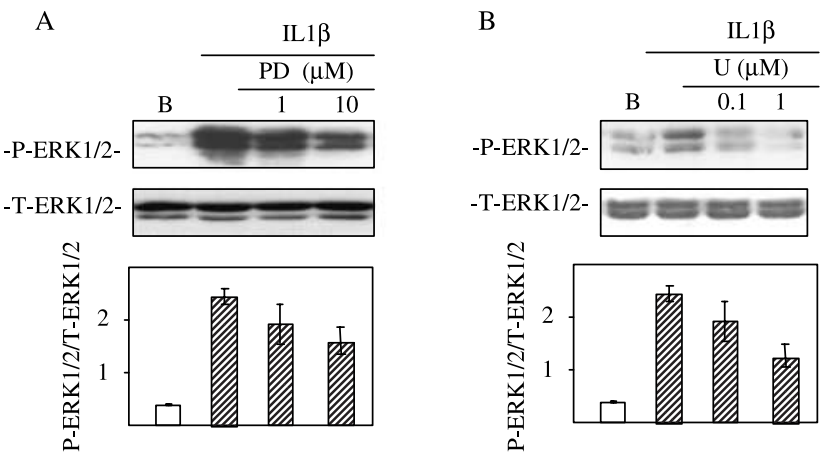

C

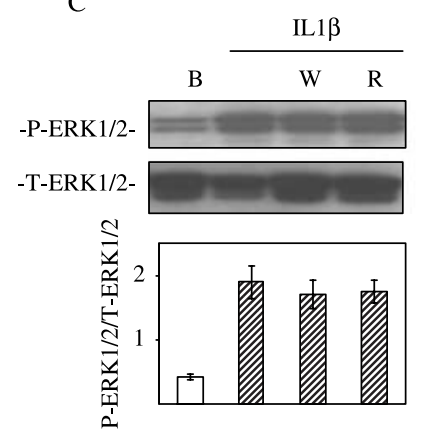

D

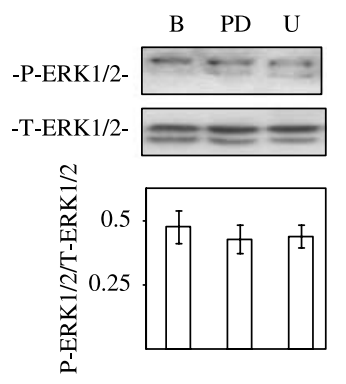

Figure 4 Effect of PD, $U, W$, and R on IL1 $\beta$-stimulated P-ERK1/2 levels in rat Sertoli cells. (A-C) Sertoli cells preincubated or not for $15 \mathrm{~min}$ with PD98059 (PD; 1 and $10 \mu \mathrm{M})$, U0126 (U; 0.1 and $1 \mu \mathrm{M})$, wortmannin (W; $0.1 \mu \mathrm{M})$, and rapamycin (R; $1 \mathrm{nM}$ ) were stimulated for $15 \mathrm{~min}$ with $50 \mathrm{ng} / \mathrm{ml} \mathrm{IL1} \beta$. (D) Sertoli cells incubated or not for $30 \mathrm{~min}$ with PD98059 (PD; $10 \mu \mathrm{M})$ or U0126 (U; $1 \mu \mathrm{M})$. Cell extracts were prepared at the designated intervals and utilized for western blot analysis using antibodies specific for P-ERK1/2 or T-ERK1/2. The upper panels show a representative experiment out of three. The lower panels show pooled data of the three independent experiments performed. Results are expressed as the mean \pm S.E.M. of the ratio between P-ERK1/2 and T-ERK1/2 in each sample.

MEK inhibitor, also decreased IL1 $\beta$ stimulation of LDH A mRNA levels (data not shown). In addition, PD98059 $(10 \mu \mathrm{M})$ and $\mathrm{U} 0126(1 \mu \mathrm{M})$ inhibited IL1 $\beta$ stimulation of LDH activity (basal: $25.1 \pm 0.9^{*}$; IL1 $\beta$ : $44.7 \pm 3.1^{\dagger}$; IL1 $\beta+$ PD98059: $37.1 \pm 1.1^{\ddagger} ; \quad$ IL1 $\beta+$ U0126: $35.3 \pm$ $2.1^{\ddagger} \mathrm{mIU} / \mu \mathrm{g}$ DNA, $X \pm$ s.D., ${ }^{*}, t,{ }^{*}$ indicate statistically significant differences, $P<0.05)$.

Table 1 Effect of W, R, and PD on interleukin-1 $\beta$ (IL1 $\beta$ ) stimulation of rat Sertoli cell $\gamma$ GTP activity.

\begin{tabular}{lc}
\hline & $\gamma$ GTP $(\mathrm{pmol} / \mu \mathrm{g}$ DNA/min) \\
\hline Basal & $22.1 \pm 1.7^{*}$ \\
IL1 $\beta$ & $43.7 \pm 1.4^{+}$ \\
IL1 $\beta+\mathrm{W}(0.1 \mu \mathrm{M})$ & $44.8 \pm 0.5^{+}$ \\
IL1 $\beta+\mathrm{R}(1 \mathrm{nM})$ & $42.8 \pm 0.8^{+}$ \\
IL1 $\beta+$ PD $(10 \mu \mathrm{M})$ & $45.8 \pm 2.1^{+}$ \\
\hline
\end{tabular}

Sertoli cells were stimulated for $72 \mathrm{~h}$ (days $3-6$ ) with $50 \mathrm{ng} / \mathrm{ml}$ IL1 $\beta$ in the absence or presence of: (A) wortmannin $(\mathrm{W} ; 0.1 \mu \mathrm{M})$, (B) rapamycin (R; $1 \mathrm{nM})$, and (C) PD98059 (PD; $10 \mu \mathrm{M})$. $\gamma$ GTP activity was determined in cells harvested on day 6 . Results represent mean \pm s.D. of triplicate incubations in one representative experiment out of three. ${ }^{*,+}$ Indicate statistically significant differences between groups $(P<0.05)$. 
Table 2 Effect of W, Ly, R, PD, and $U$ on Sertoli cell viability.

\begin{tabular}{lcc}
\hline & \multicolumn{2}{c}{ Cell viability (\% of control; $h)$} \\
\cline { 2 - 3 } & 3 & 72 \\
\hline Basal & 100 & 100 \\
W $(0.1 \mu \mathrm{M})$ & $100 \pm 4$ & $98 \pm 4$ \\
Ly $(25 \mu \mathrm{M})$ & $95 \pm 6$ & $53 \pm 12^{*}$ \\
$\mathrm{R}(1 \mathrm{nM})$ & $101 \pm 2$ & $99 \pm 5$ \\
$\mathrm{PD}(10 \mu \mathrm{M})$ & $93 \pm 7$ & $96 \pm 6$ \\
U $(1 \mu \mathrm{M})$ & $98 \pm 4$ & $100 \pm 4$
\end{tabular}

Sertoli cells were incubated for 3 or $72 \mathrm{~h}$ without (basal) or with wortmannin (W), LY294002 (Ly), rapamycin (R), PD98059 (PD), and U0126 (U). The cell viability assay was performed on day 6 . Data are expressed as percentage of basal conditions and are presented as mean \pm S.D. of triplicate incubations in one representative experiment out of three $\left({ }^{*} P<0.01\right.$ versus basal).

\section{Discussion}

Nearly, every known signal transduction pathway has been reported to be activated in response to IL1 $\beta$. However, the significance of many of these signaling events is unclear due to the use of different, and sometimes unique, cell lines in studying IL1 $\beta$-initiated signal transduction.

In Sertoli cells, IL1 $\beta$ regulates estradiol production (Khan \& Nieschlag 1991), transferrin and gelatinase A secretion (Hoeben et al. 1996a, 1996b), lactate production (Nehar et al. 1998, Riera et al. 2001), IL6 expression (Okuda et al. 1995), rGTP activity (Meroni et al. 2000) and proliferation (Petersen et al. 2002) among other functions. However, with few exceptions, the above-mentioned studies have not investigated the signal transduction pathways utilized by this cytokine to regulate Sertoli cell biological functions. As mentioned before, we have shown that IL1 $\beta$ utilizes an NO-dependent pathway to regulate $\gamma$ GTP activity (Meroni et al. 2000). In addition, Ishikawa et al. (2005) have shown that the expression of some proteins related to lipid transport is IL1 $\beta$ regulated by activation of JNK and cyclooxygenase- 2 . They claimed in their report that IL1 $\beta$ is not able to activate PKB and ERK1/2. In sharp contrast to Ishikawa et al. findings, we have observed that IL1 $\beta$ induces time-dependent activation of PKB-, P70S6K-, and ERK1/2-signaling pathways in rat Sertoli cells. This discrepancy is difficult to explain considering that only subtle experimental differences, some related to the stimulation-time schedule, were detected between their work and ours. Activation of the above-mentioned signal transduction pathways reached maximal values in 15-min incubations for P-PKB and P-ERK1/2 and in 30-min incubations for P-P70S6K. As expected, inhibition of PI3K activity with wortmannin and LY294002 decreased P-PKB and P-P70S6K levels but did not modify P-ERK1/2 levels, inhibition of mTOR activity with rapamycin decreased P-P70S6K levels but did not modify P-PKB and P-ERK1/2 levels, and inhibition of MEK activity by PD98059 and U0126 decreased
A

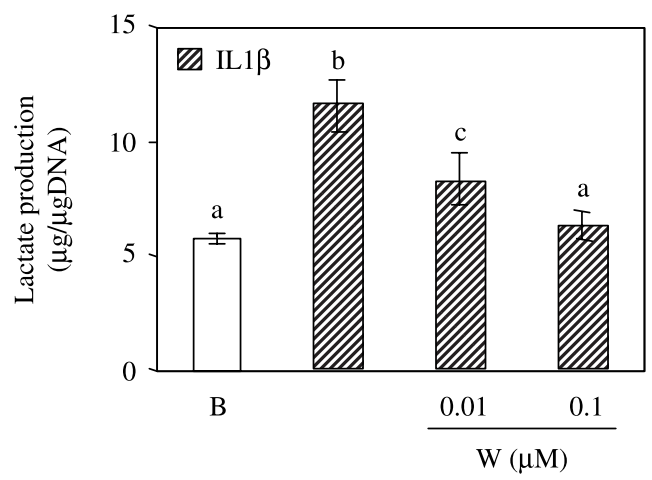

B

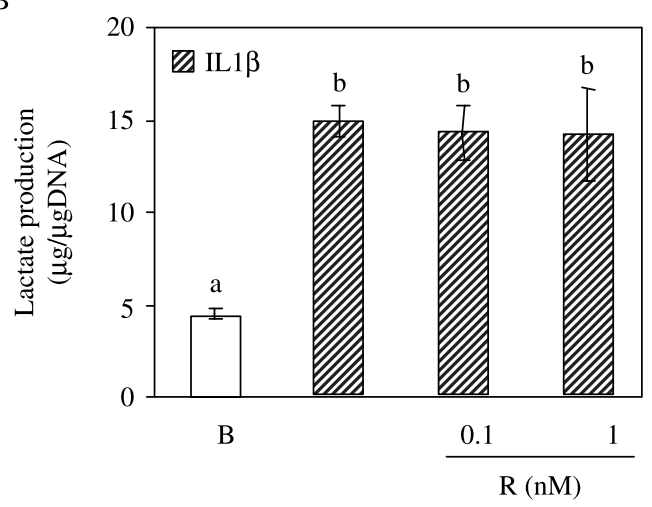

C

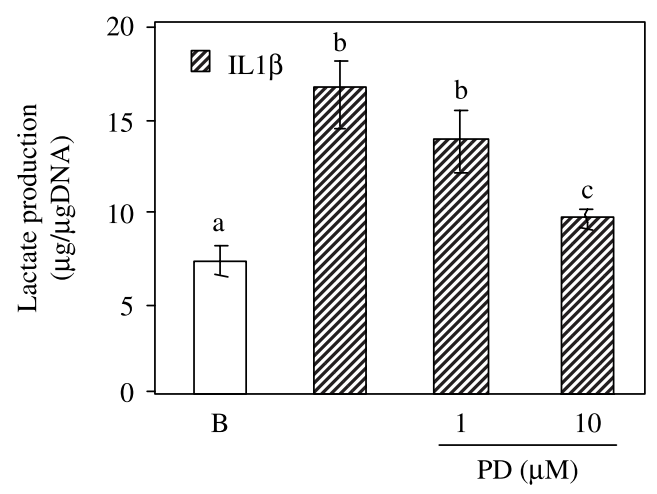

Figure 5 Effect of $W, R$, and PD on IL1 $\beta$ stimulation of lactate production in Sertoli cells. Sertoli cells were stimulated for $72 \mathrm{~h}$ (days 3-6) with $50 \mathrm{ng} / \mathrm{ml} \mathrm{IL1} \beta$ in the absence or presence of two doses of: (A) wortmannin (W; 0.01 and $0.1 \mu \mathrm{M})$, (B) rapamycin ( $R$; 0.1 and $1 \mathrm{nM}$ ), and (C) PD98059 (PD; 1 and $10 \mu \mathrm{M}$ ). Lactate was determined in the 72 -h conditioned media recovered on day 6 . Results represent mean \pm S.D. of triplicate incubations in one representative experiment out of three. Different letters indicate statistically significant differences between groups $(P<0.05)$.

P-ERK1/2 levels but did not modify P-PKB and P-P70S6K levels. Thus, the use of the above-mentioned inhibitors in combination with IL1 $\beta$ stimulation constituted a useful tool to analyze to what extent these pathways are involved in IL1 $\beta$ regulation of Sertoli cell differentiated function. 
Table 3 Effect of R on IL1 $\beta$ stimulation of rat Sertoli cell transferrin secretion.

\begin{tabular}{lc}
\hline & Transferrin $(\mathrm{ng} / \mu \mathrm{g}$ DNA) \\
\hline Basal & $100 \pm 21^{*}$ \\
IL1 $\beta$ & $277 \pm 20^{+}$ \\
IL1 $\beta+R(1 \mathrm{nM})$ & $166 \pm 19^{\ddagger}$ \\
\hline
\end{tabular}

Sertoli cells were stimulated for $72 \mathrm{~h}$ (days 3-6) with $50 \mathrm{ng} / \mathrm{ml} \mathrm{IL1 \beta}$ in the absence or presence of rapamycin $(\mathrm{R} ; 1 \mathrm{nM})$. Transferrin was determined in the $72-\mathrm{h}$ conditioned media recovered on day 6 . Results represent mean \pm s.D. of triplicate incubations in one representative experiment out of three. ${ }^{*, t, \neq}$ Indicate statistically significant differences between groups $(P<0.05)$

Activation of $\mathrm{PI} 3 \mathrm{~K} / \mathrm{PKB}$ pathway by $\mathrm{FSH}$ and basic fibroblast growth factor (bFGF) has been previously shown to be associated with the support of differentiated functions of Sertoli cells (Meroni et al. 2002, Riera et al. 2003). On the other hand, the ERK $1 / 2$ pathway, first recognized by its association with cell division, has been related to a diverse array of cellular processes. At 20 days of age in the rat, Sertoli cells have lost their ability to undergo mitosis. Therefore, it may be assumed that activation of the ERK1/2 pathway by IL $1 \beta$ might also be related to the regulation of Sertoli cell differentiated functions as it was demonstrated for bFGF (Riera et al. 2003). Activation of P70S6K by IL1 $\beta$ may be related to the maintenance of the differentiated state of Sertoli cells as well. In agreement with this latter hypothesis, a recent report describes P70S6K activation by FSH, the Sertoli cell tropic hormone (Lecureuil et al. 2005).

The present study shows that IL1 $\beta$ stimulation of lactate production is inhibited by wortmannin and PD98059, while it is not modified by rapamycin. These results suggest that a PI3K/PKB- and an ERK1/2dependent pathway participate in the regulation of lactate production by IL1 $\beta$. Since rapamycin may be lost during 72-h incubations, we looked for a positive control in order to rule out this possibility. We have analyzed the effect of rapamycin on IL1 $\beta$-stimulated transferrin production in 72-h incubations. We observed that rapamycin inhibits IL1 $\beta$ stimulation of transferrin secretion suggesting that, on the one hand, an mTOR pathway participates in IL1 $\beta$ regulation of transferrin production and, on the other hand, that the inhibitor is active over this period of time.

Glucose transport into the cell and the LDH isoenzyme system, which reversibly catalyzes the interconversion of pyruvate and lactate, are biochemical steps that participate in the regulation of lactate production. Facilitated Sertoli cell glucose transport across plasma membrane is mediated by the carrier proteins termed glucose transporters 1, 3, and 8 (GLUT1, GLUT3, and GLUT8), the glucose transporters so far demonstrated in this cell (Ulisse et al. 1992, Kokk et al. 2004, Carosa et al. 2005). As for the LDH isoenzyme system, increments in lactate production in rat Sertoli cells have been correlated with an increase in the LDH5
A

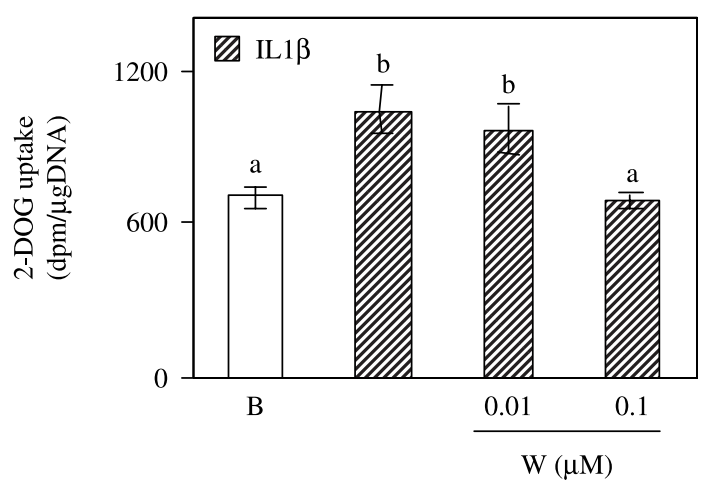

B

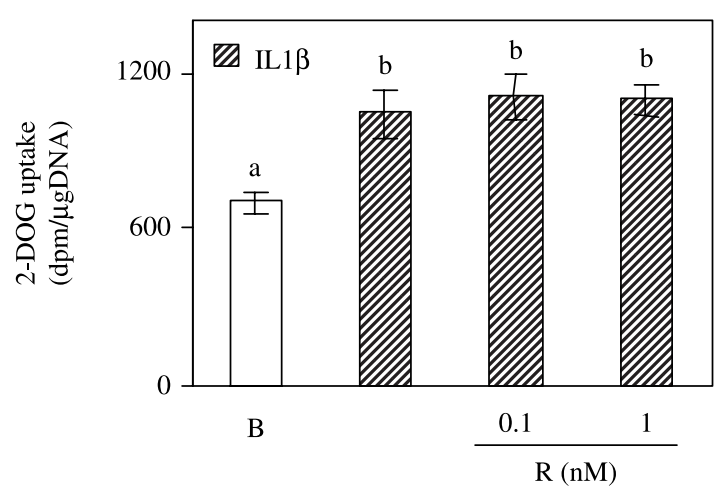

$\mathrm{C}$

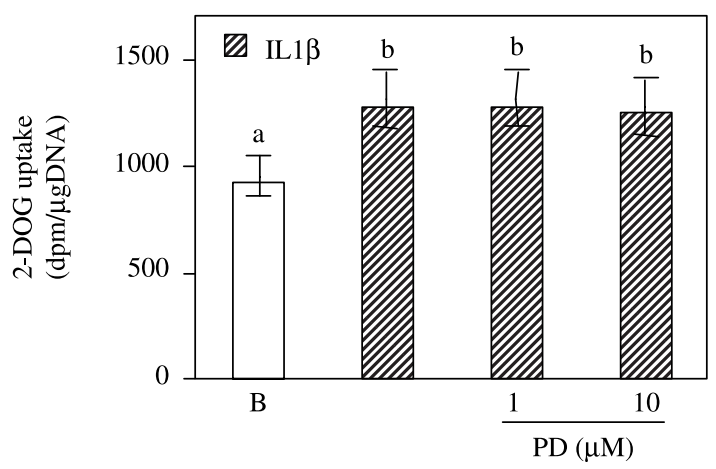

Figure 6 Effect of W, R, and PD on IL1 $\beta$ stimulation of Sertoli cell 2-DOG uptake. On day 5 in culture, Sertoli cells were stimulated for $60 \mathrm{~min}$ with $50 \mathrm{ng} / \mathrm{ml}$ IL1 $\beta$ in the absence or presence of two doses of: (A) wortmannin (W; 0.01 and $0.1 \mu \mathrm{M})$, (B) rapamycin ( $R ; 0.1$ and $1 \mathrm{nM})$, and (C) PD98059 (PD; 1 and $10 \mu \mathrm{M}$ ). 2-DOG uptake assay was performed after this incubation period. Results represent mean \pm s.D. of triplicate incubations in one representative experiment out of three. Different letters indicate statistically significant differences between groups $(P<0.05)$.

isoenzyme - containing four subunits A - and in LDH A mRNA levels. Particularly, increments in glucose uptake, LDH activity, and LDH A mRNA levels participate in the regulation of lactate production by IL1 $\beta$ in the rat Sertoli cells (Riera et al. 2001). Considering that our results showed a participation of PI3K/PKB- and ERK1/2-signaling 

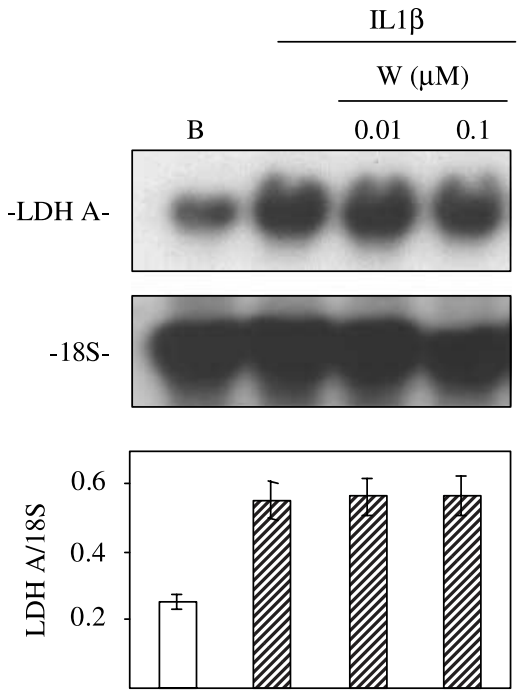

B
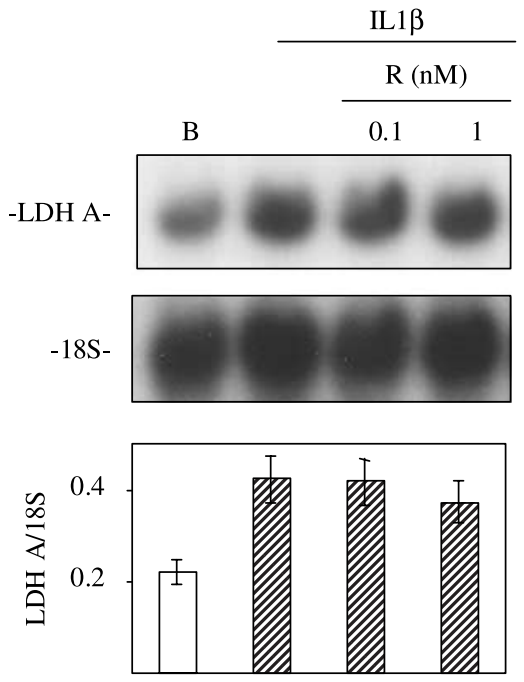

C
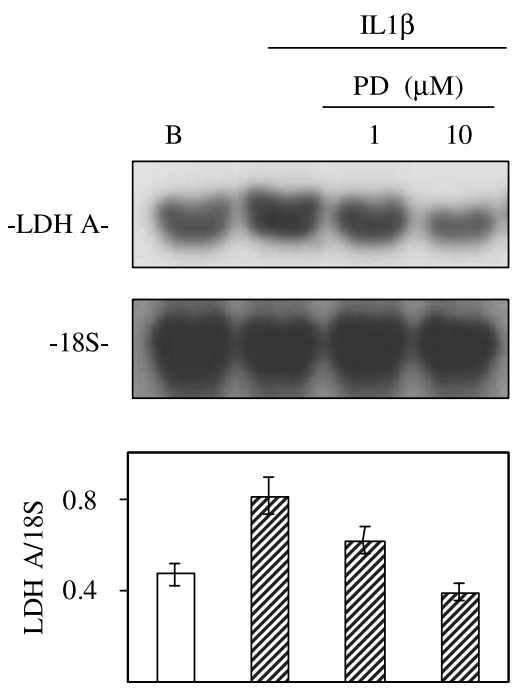

pathways in the regulation of lactate production by IL1 $\beta$, we decided to analyze the possible involvement of these signaling pathways in the regulation of the abovementioned metabolic steps. Even though P70S6K did not seem to be involved in the regulation of lactate production, the participation of this signaling pathway in glucose uptake and LDH A mRNA levels deserved further investigation.

As for the regulation of glucose transport by IL1 $\beta$, we observed that wortmannin is the only inhibitor able to decrease IL1 $\beta$-stimulated glucose transport, suggesting the participation of a PI3K-dependent pathway. The latter pathway, originally described in relation to the mechanism of action of insulin (Okada et al. 1994, Czech \& Corvera 1999), has been demonstrated to participate in the regulation of $\mathrm{FSH}$ - and bFGFstimulated glucose uptake in rat Sertoli cells (Meroni et al. 2002, Riera et al. 2003). Altogether, these results suggest that activation of the PI3K/PKB-signaling pathway may constitute a universal mechanism that participates in the regulation of glucose transport into different cell types and by different extracellular signals.

Concerning LDH A mRNA levels, stimulation by IL1 $\beta$ was impaired in the presence of the MEK inhibitors, but not in the presence of the PI3K inhibitor or the mTOR inhibitor. Confirming the previous result, we have observed that the MEK inhibitors also inhibited IL1 $\beta$ stimulated LDH activity. These results seem to indicate that, different from what was observed for glucose transport, an ERK1/2-dependent pathway participates in the regulation of LDH A mRNA levels and $\mathrm{LDH}$ activity. The latter results are similar to those previously observed for the regulation of LDH activity by bFGF (Riera et al. 2003).

In a previous report (Riera et al. 2001), we have shown that IL1 $\beta$ increases total LDH activity and modifies the distribution profile of LDH isoenzymes by increasing $\mathrm{LDH} 4$ and $\mathrm{LDH} 5$ and decreasing $\mathrm{LDH} 1$ and $\mathrm{LDH} 2$. The mechanisms involved in the increase of $\mathrm{LDH} 4$ and $\mathrm{LDH} 5$ may be related to the observed increase in LDH A mRNA levels. Other authors have also related LDH A expression to LDH5 activity (Nehar et al. 1993, 1998). Since the MEK inhibitors decreased IL1 $\beta$ stimulation of LDH A mRNA levels, we suggest that the inhibition of LDH activity is mainly due to a decrease in those

Figure 7 Effect of W, R, and PD on IL1 $\beta$ stimulation of Sertoli cell LDH A mRNA levels. Sertoli cells were stimulated for $48 \mathrm{~h}$ (days 3-5) with $50 \mathrm{ng} / \mathrm{ml} \mathrm{IL1} \beta$ in the absence or presence of two doses of: (A) wortmannin (W; 0.01 and $0.1 \mu \mathrm{M})$, (B) rapamycin ( $R ; 0.1$ and $1 \mathrm{nM}$ ), and (C) PD98059 (PD; 1 and $10 \mu \mathrm{M}$ ). Total cellular RNAs were then extracted and northern blotting analysis was performed using $20 \mu \mathrm{g}$ total RNA per lane. Membranes were hybridized with labeled cDNA probes for LDH A and 185 as described in Materials and Methods. The upper panels show a representative experiment out of three. The lower panels show pooled data of the three independent experiments performed. Results are expressed as the mean \pm S.E.M. of the ratio between LDH A and $18 \mathrm{~S}$ in each sample. 
isoenzymes that contain higher proportions of $\mathrm{A}$ subunits.

A kinetic study of IL1 $\beta$ action on LDH A mRNA levels shows that maximal levels of mRNA are observed after a 48-h incubation period. These results are identical to those found by Nehar et al. (1998) for IL1 $\alpha$ action in immature pig Sertoli cells. Prolonged treatments always raise the question of whether the observed effects of IL1 $\beta$ are direct or indirect through the stimulation of other cytokines or prostaglandins. In this context, Nehar et al. (1998) have proposed that IL6 might be a mediator of IL1 $\alpha$ response. In addition, Ishikawa \& Morris (2006) have proposed that an autocrine-amplifying loop that involves COX-2-induced PGE2 and PGF2 $\alpha$ production participates in the IL1 $\beta$-regulated Sertoli cell function. Considering that IL6, PGE2, and PGF2 $\alpha$ stimulate ERK1/ 2 in other cell types (Lin et al. 2001, Kanda et al. 2005, Sales et al. 2005), the participation of this pathway in relation to these other hormones, but not to IL $1 \beta$, cannot be ruled out. However, taking into account that a preincubation with PD98059 or U0126 is necessary to observe the effect of the inhibitors on IL1 $\beta$ stimulation of LDH A mRNA levels, it is tempting to speculate that IL1 $\beta$ itself stimulates an ERK1/2 pathway that is related to the regulation of this biological response.

In this investigation, regulation of lactate production by IL1 $\beta$ can be accounted for by the regulation of glucose uptake and LDH activity. However, other mechanisms such as modification of lactate export or the activity of enzymes of the glycolytic pathway (not analyzed in this paper) might also participate in the regulation of lactate production.

As previously mentioned, the action of IL1 $\beta$ on $\gamma$ GTP activity is partially mediated via cellular production of NO (Meroni et al. 2000). In the present study, we have observed that, on the one hand, stimulation of $\gamma$ GTP activity by IL1 $\beta$ is not inhibited by wortmannin, rapamycin, or PD98059 and, on the other hand, that an inhibitor of iNOS does not modify IL $1 \beta$ stimulation of lactate production. Taken together, these results suggest that IL1 $\beta$ utilizes PI3K/PKB- and ERK1/2-dependent pathways to regulate the different biochemical steps involved in the lactate production and an NO-dependent pathway to regulate the $\gamma$ GTP activity.

In summary, our results suggest that IL1 $\beta$ activates PKB-, P70S6K-, and ERK1/2-dependent pathways in rat Sertoli cells. Moreover, these results show that while IL1 $\beta$ utilizes the PI3K/PKB pathway to regulate glucose transport, it utilizes the ERK1/2 pathway to regulate LDH activity and LDH A mRNA levels. This study reveals the different utilization of the pathways elicited by IL $1 \beta$ to regulate distinct biochemical steps that are important to regulate lactate production in rat Sertoli cells. The overall picture suggests that different signal transduction pathways activated by the same extracellular signal can regulate specific biological responses.

\section{Acknowledgements}

The authors express their gratitude to $\mathrm{Dr} R$ Jungmann, Northwestern University Medical School (Chicago, IL, USA) for providing LDH A cDNA. The technical help of Mercedes Astarloa is gratefully acknowledged. The authors also thank Celia Nieto for revising our English usage.

\section{Funding}

The work was supported by grants from the Agencia Nacional de Promoción Científica y Tecnológica (PICTs 8681 and 25365) and CONICET (PIP 5479). The authors declare that there is no conflict of interest that would prejudice the impartiality of this scientific work.

\section{References}

Alessi D, Andjelkovic M, Caudwell B, Cron P, Morrice N, Cohen P \& Hemmings B 1996 Mechanism of activation of protein kinase B by insulin and IGF-I. EMBO Journal 15 6541-6551.

Carosa E, Radico C, Giansante N, Rossi S, D'Adamo F, Di Stasi SM, Lenzi A \& Jannini EA 2005 Ontogenetic profile and thyroid hormone regulation of type- 1 and type- 8 glucose transporters in rat Sertoli cells. International Journal of Andrology 28 99-106.

Czech MP \& Corvera S 1999 Signaling mechanisms that regulate glucose transport. Journal of Biological Chemistry 274 1865-1868.

Finch A, Davis W, Carter WG \& Saklatvala J 2001 Analysis of mitogenactivated protein kinase pathways used by interleukin 1 in tissues in vivo: activation of hepatic c-Jun $\mathrm{N}$-terminal kinases 1 and 2, and mitogen-activated protein kinase kinases 4 and 7 . Biochemical Journal 53 275-281.

Gnessi L, Fabbri A \& Spera G 1997 Gonadal peptides as mediators of development and functional control of the testis: an integrated system with hormones and local environment. Endocrine Reviews 18 541-609.

Gomez E, Morel G, Cavalier A, Lienard MO, Haour F, Courtens JL \& Jegou B 1997 Type I and type II interleukin-1 receptor expression in rat, mouse and human testes. Biology of Reproduction $\mathbf{5 6}$ 1513-1526.

Gould GW, Cuenda A, Thomson FJ \& Cohen P 1995 The activation of distinct mitogen-activated protein kinase cascades is required for the stimulation of 2-deoxyglucose uptake by interleukin-1 and insulinlike growth factor-1 in KB cells. Biochemical Journal 311 735-738.

Handelsman DJ, Spaliviero JA, Kidston E \& Robertson DM 1989 Highly polarized secretion of inhibin by Sertoli cells in vitro. Endocrinology 125 721-729.

Hayes R, Chalmers SA, Nikolic-Paterson DJ, Atkins RC \& Hedger MP 1996 Secretion of bioactive interleukin 1 by rat testicular macrophages in vitro. Journal of Andrology 17 41-49.

Hoeben E, Van Damme J, Put W, Swinnen J \& Verhoeven G 1996a Cytokines derived from activated human mononuclear cells markedly stimulates transferrin secretion by cultured Sertoli cells. Endocrinology 137 514-521.

Hoeben E, Van Aelst I, Swinnen JV, Opdenakker G \& Verhoeven G $1996 b$ Gelatinase A secretion and its control in peritubular and Sertoli cell cultures: effects of hormones, second messengers and inducers of cytokine production. Molecular and Cellular Endocrinology 118 37-46.

Ishikawa T \& Morris P 2006 A multistep kinase-based Sertoli cell autocrine-amplifying loop regulates prostaglandins, their receptors and cytokines. Endocrinology 147 1706-1716.

Ishikawa T, Hwang K, lazzarino D \& Morris PL 2005 Sertoli cell expression of STARD1 and D5 START domain containing proteins 
and SREBP- 1 are IL1 $\beta$ regulated by activation of c-Jun N-terminal kinase and ciclooxygenase-2 and cytokine induction. Endocrinology 146 5100-5111.

Kanda N, Koike S \& Watanabe S 2005 Prostaglandin E2 enhances neurotrophin-4 production via EP3 receptor in human keratinocytes. Journal of Pharmacological and Experimental Therapeutics 315 796-804.

Khan SA \& Nieschlag E 1991 Interleukin-1 inhibits follitropin-induced aromatase activity in immature rat Sertoli cells in vitro. Molecular and Cellular Endocrinology 75 1-7.

Kokk K, Veraiankorva E, Wu XK, Tapfer H, Poldoia E \& Pollanen P 2004 Immunohistochemical detection of glucose transporters class I subfamily in the mouse, rat and human testis. Medicina 40 156-160.

Labarca C \& Paigen K 1980 A simple, rapid and sensitive DNA assay procedure. Analytical Biochemistry 102 344-352.

Laemmli UK 1970 Cleavage of structural proteins during the assembly of the head of bacteriophage T4. Nature 227 680-685.

Lecureuil C, Tesseraud S, Kara E, Martinat N, Sow A, Fontaine I, Gauthier C, Rieter E, Guillou F \& Crepieux P 2005 Folliclestimulating hormone activates $\mathrm{p} 70$ ribosomal protein $\mathrm{S} 6$ kinase by protein kinase A-mediated dephosphorylation of Thr 421/Ser 424 in primary Sertoli cells. Molecular Endocrinology 19 1812-1820.

Lin T, Wang D \& Napgal MN 1993 Human chorionic gonadotropin induces interleukin-1 gene expression in rat Leydig cells in vivo. Molecular and Cellular Endocrinology 95 139-145.

Lin DL, Whitney MC, Yao Z \& Keller ET 2001 Interleukin-6 induces androgen responsiveness in prostate cancer cells through up-regulation of androgen receptor expression. Clinical Cancer Research 7 1773-1781.

Lowry OH, Rosebrough NJ, Farr AL \& Randall RJ 1951 Protein measurement with the Folin phenol reagent. Journal of Biological Chemistry 193 265-275.

Martin KA, Schalm SS, Richardson C, Romanelli A, Keon KL \& Blenis J 2001 Regulation of ribosomal S6 kinase 2 by effectors of the phosphoinositide 3-kinase pathway. Journal of Biological Chemistry 276 7884-7891.

Meroni SB, Cánepa DF, Pellizzari EH, Schteingart HF \& Cigorraga SB 1999 Effect of $\mathrm{N}$-acetylsphingosine (c2) and ceramidase inhibitor (1S,2R)-D-erythro-2-( $\mathrm{N}$-myristoylamino)-1-phenyl-1-propanol on the regulation of Sertoli cell function. Journal of Andrology 20 619-625.

Meroni SB, Suburo M \& Cigorraga SB 2000 Interleukin-1 $\beta$ regulates nitric oxide production and $\gamma$ glutamyl transpeptidase activity in Sertoli cells. Journal of Andrology 21 855-861.

Meroni SB, Riera MF, Pellizzari EH \& Cigorraga SB 2002 Regulation of rat Sertoli cell function by FSH: possible role of phosphatidylinositol 3-kinase/protein kinase B pathway. Journal of Endocrinology 174 195-204.

Nehar D, Mauduit C, Revol A, Morera AM \& Benahmed M 1993 Effect of epidermal growth factor/transforming growth factor alpha on lactate production in porcine Sertoli cells: glucose transport and lactate dehydrogenase isozymes as potential sites of action. Molecular and Cellular Endocrinology 92 45-53.

Nehar D, Mauduit C, Boussouar F \& Benahmed M 1998 Interleukin $1 \alpha$ stimulates lactate dehydrogenase A expression and lactate production in cultured porcine Sertoli cells. Biology of Reproduction 59 $1425-1432$.

Okada T, Kawano Y, Sakakibara T, Hazeki O \& Ui M 1994 Essential role of phosphatidylinositol 3-kinase in insulin-induced glucose transport and antilipolysis in rat adipocytes. Journal of Biological Chemistry $2693568-3573$.
Okuda Y, Bardin CW, Hodgskin L \& Morris P 1995 Interleukins $1 \alpha$ and $1 \beta$ regulate interleukin- 6 expression in Leydig and Sertoli cells. Recent Progress in Hormone Research 50 367-372.

Orlowsky M \& Meister A $1963 \gamma$-Glutamyl-p-nitroanilide: a new convenient substrate for determination and study of $L$-and $D-\gamma$ glutamyltranspeptidase activities. Biochemical Biophysical Acta $\mathbf{7 3}$ 679-681.

Pearson G, Robinson F, Beers Gibson T, Xu BE, Karandikar M, Berman K \& Cobb MH 2001 Mitogen-activated protein (MAP) kinase pathways: regulation and physiological functions. Endocrine Reviews 22 153-183.

Petersen C, Boitani C, Froysa B \& Soder O 2002 Interleukin-1 is a potent growth factor for immature rat Sertoli cells. Molecular and Cellular Endocrinology 186 37-47.

Proud CG 1996 P70 S6 kinase: an enigma with variations. Trends in Biochemical Sciences 21 181-185.

Pullen N \& Thomas G 1997 The modular phosphorylation and activation of P70S6K. FEBS Letters 410 78-82.

Rameh L \& Cantley LC 1999 The role of phosphoinositide 3-kinase lipid products in cell function. Journal of Biological Chemistry $\mathbf{2 7 4}$ 8347-8350.

Reddy SA, Huang JH \& Liao WS 1997 Phosphatidylinositol 3-kinase in interleukin-1 signalling. Physical interaction with the interleukin-1 receptor and requirement in NF-kB and AP-1 activation. Journal of Biological Chemistry 272 29167-29173.

Riera MF, Meroni SB, Gomez GE, Schteingart HF, Pellizzari EH \& Cigorraga SB 2001 Regulation of lactate production by FSH, IL1 $\beta$ and TNF $\alpha$ in rat Sertoli cells. General and Comparative Endocrinology 122 88-97.

Riera MF, Meroni SB, Pellizzari EH \& Cigorraga SB 2003 Assessment of the roles of mitogen-activated protein kinase and phosphatidyl inositol 3-kinase/protein kinase B pathways in the basic fibroblast growth factor regulation of Sertoli cell function. Journal of Molecular Endocrinology 31 279-289.

Sales KJ, List T, Boddy SC, Williams AR, Anderson RA, Naor Z \& Jabbour HN 2005 A novel angiogenic role for prostaglandin F2alpha-FP receptor interaction in human endometrial adenocarcinomas. Cancer Research 65 7707-7716.

Schteingart HF, Meroni SB, Pellizzari EH, Loaiza Pérez A \& Cigorraga SB 1995 Regulation of Sertoli cell aromatase activity by cell density and prolonged stimulation with FSH, EGF, Insulin and IGF-I at different moments of pubertal development. Journal of Steroid Biochemistry and Molecular Biology 52 375-381.

Sizemore N, Leung S \& Stark GR 1999 Activation of phosphatidylinositol 3-kinase in response to interleukin-1 leads to phosphorylation and activation of the NF- $\mathrm{kB}$ p65/Rel A subunit. Molecular and Cellular Biology 19 4798-4805.

Ulisse S, Jannini EA, Pepe M, De Matteis S \& D'Armiento M 1992 Thyroid hormone stimulates glucose transport and GLUT1 mRNA in rat Sertoli cells. Molecular and Cellular Endocrinology 87 131-137.

Vanhaesebroeck B \& Alessi D 2000 The PI3K-PDK1 connection: more than just a road to pkB. Biochemical Journal 346 561-576.

Received 22 December 2005

First decision 9 March 2006

Revised manuscript received 4 December 2006

Accepted 21 December 2006 